\title{
UJI MACAM PENYIRAMAN TERHADAP HASIL UWI ( Dioscorea allata )
}

\author{
Sri Hardiatmi dan Endang Sri Sudalmi \\ Fakultas Pertanian Universitas Slamet Riyadi Surakarta \\ Jl. Sumpah Pemuda No.18 Kadipiro Surakarta \\ Email : srihardiatmi@ unisri.ac.id
}

\begin{abstract}
ABSTRAK
Penelitian ini bertujuan untuk mengetahui pengaruh macam penyiraman terhadap hasil uwi Rancangan yang digunakan dalam penelitian ini adalah Rancangan Acak Lengkap ( RAL ) dengan faktor tunggal yang terdiri dari tujuh perlakuan macam penyiraman ( $\mathrm{P}$ ), sebagai berikut : $\mathrm{P} 0=$ Penyiraman dengan air (kontrol), (2) $\mathrm{P} 1=$ Penyiraman dengan leri 1 gelas, (3) $\mathrm{P} 2$ = Penyiraman dengan leri 2 gelas, (4) P3 = Penyiraman dengan leri 3 gelas, (5) P4 = Penyiraman dengan ekstrak teh 1 gelas, (6) P5 = Penyiraman dengan ekstrak teh 2 gelas,( 7) P6 = Penyiraman dengan ekstrak teh 3 gelas. Masing - masing perlakuan diulang 4 kali, sehingga keseluruhan ada 28 satuan perlakuan penelitian. Data hasil penelitian ini dianalisis dengan menggunakan analisis ragam, dilanjutkan dengan uji ( BNJ ) pada taraf $5 \%$. Hasil penelitian menunjukkan bahwa (1) Penyiraman tanaman uwi menggunakan leri dosis 3 gelas dapat meningkatkan secara nyata komponen hasil uwi yaitu jumlah umbi dan berat bulbil. (2) Penyiraman tanaman uwi menggunakan ekstrak teh dengan dosis 3 gelas dapat meningkatkan secara nyata komponen hasil uwi yaitu jumlah umbi, berat umbi, volume umbi, berat bulbil, dan volume bulbil. (3) Penyiraman tanaman uwi menggunakan ekstrak teh dengan dosis 3 gelas akan menghasilkan umbi terberat yaitu $1242,50 \mathrm{~g} / \mathrm{tanaman}$.
\end{abstract}

Kata kunci : Air leri, Air ekstrak teh, Hasil umbi uwi

\section{ABSTRACT}

The aim of this research was to know the effect of different watering treatment toward the result of Uwi plantation. The sample that is used in this research was Complete Random Design (CRD) with singular factor that consist of seven different kinds of treatment $(P)$, as mentioned below:

$P 0=$ Watering treatment with water (control), (2) $P 1=$ Watering treatment by using 1 glass of water from the rice, (3) P2 = Watering treatment by using 2 glass of water from the rice, (4) $P 3=$ Watering treatment by using 3 glass of water from the rice (5) P4 Watering treatment by using one glass of water from the tea extract, (6) P5 = Watering treatment by using 2 glass of water from the tea extract,(7) $P 6=$ Watering treatment by using 3 glass of water from the tea extract.

Each of those treatment is repeated 4 times, so there are all 28 units in treatment. The data ofthis research is analized by using varied analize method continued with BNJ in $5 \%$ level. The result show that (1) the watering treatment by using water from rice with 3 glasses dosage can increase the harvest of the uwi and also the bulbil weight of each harvest. (2) the watering treatment by using water from the tea extract with 3 glasses dosage can increase the harvest result significantly in term of the numbers, volume, and the wight of the umbi and also the weight and the volume of the bulbil. (3) the watering treatment by using water from the tea extract with 3 glasses dosage grew the heaviest uwi of all which is $1242,50 \mathrm{~g} /$ plant.

Key Word: water from the rice, water from the extract, Umbi Uwi 


\section{PENDAHULUAN}

\section{Latar Belakang}

Pangan merupakan

kebutuhan utama bagi manusia yang harus dipenuhi agar kelangsungan hidup seseorang dapat dijamin. Indonesia merupakan salah satu negara berkembang yang hingga sekarang masih terkenal dengan mata pencaharian sebagian besar penduduknya sebagai petani, bercocok tanam.

Dewasa ini Indonesia menghadapi masalah serius dalam situasi pangan dimana yang menjadi kebutuhan pokok semua orang. Pangan merupakan masalah serius yang sedang hangat diperbincangkan, baik pada tataran daerah, nasional, regional maupun global. Hal ini berkaitan dengan kejadian rawan pangan yang sedang terjadi diberbagai belahan bumi. Kejadian rawan pangan secara global disebabkan oleh ketidakseimbangan antara ketersediaan dan permintaan pangan yang merupakan implikasi langsung dari ketidakseimbangan peningkatan jumlah penduduk dan peningkatan produktifitas pertanian sehingga tanaman yang dipandang rendah seperti uwi menjadi sasaran utama masyarakat untuk dikonsumsi dalam keadaan rawan pangan akibat musim kemarau yang berkepanjangan (Yuliana A.O,2011).

Berdasarkan fakta tersebut, kiranya dibutuhkan bahan pangan alternatif yang dapat mensubstitusi beras sebagai makanan pokok yang semakin sulit dikembangkan karena keterbatasan lahan irigasi yang sudah banyak dikonversi menjadi lahan industri dan perumahan.

Tanaman uwi adalah tanaman pokok berpati yang sangat penting dalam pertanian tropika dan sub tropika. Tanaman ini dapat dikatakan tanaman pangan subsistem khusus bagi petani miskin, tetapi makin meningkat menjadi tanaman yang lebih komersial dan umumnya lebih disukai dari pada ubikayu.

Di indonesia tidak ada data statistik nasional, tetapi tercatat adanya budidaya dan pemanfaatannya sebagai bahan pangan dibeberapa daerah (Anonim, 2015).

Beberapa faktor mengindikasikan kepentingan Indonesia untuk mengembangkan produksi uwi dan pemanfaatannya 
sebagai bahan pangan alternatif. Selain dalam kontek diversifikasi pangan ,juga untuk menghadirkan pilihan baru pangan fungsional, khususnya untuk pencegahan dan pengendalian penyakit diabetes yang merupakan salah satu penyakit serius di Indonesia dengan jumlah penduduk nomor empat di dunia. Pangan berbahan uwi dapat membantu pengendalian diabetes karena kadar gulanya rendah dan indek glikemik (IG)nya juga rendah sekitar 22-24.

Kandungan amilosa dan serat makanan juga tinggi sehingga baik untuk dikonsumsi penderita diabetes. Di Indonesia Spesies uwi masih dibudidayakan secara kecil-kecilan atau sambilan di beberapa daerah seperti Jawa Tengah, Jawa Timur, Kalimantan Selatan, Sulawesi Tenggara, dan Maluku. Di beberapa daerah tanaman genus ubi-ubian merupakan tanaman liar atau ditanam secara tidak konsisten (Anonim, 2015).

Diakui bahwa masa dormansi umbi uwi cukup lama, tetapi untuk pengadaan bibit sudah ada teknik yang dapat mempersingkat masa dormansi mejadi satu bulan.
Perbanyakan uwi dapat menggunakan umbi kecil,bulbil atau potongan umbi(Bagian umbi). Umbi bibit yang berbobot 100-150 g biasanya digunakan secara utuh. Potongan kepala(mahkota umbi) seberat $250 \mathrm{~g}$ dianggap sebagai bahan perbanyakan yang ideal karena pertunasan seragam dan produktivitasnya tinggi. Bulbil menghasilkan umbi yang lebih kecil dan biasanya memerlukan periode pertumbuhan yang lebih panjang sebelum tanaman dipanen. Umbi bibit potongan seberat 200-300 g digunakan jika umbi berukuran kecil tidak tersedia. Ujung proksimal (dekat batang) lebih disukai karena menghasilkan pertumbuhan batang terbaik, diikuti bagian tengah, dan terjelek adalah bagian ujung distal ( jauh dari batang). Umbi bibit potongan dapat digunakan untuk mengatasi rendahnya laju penggandaan bahan perbanyakan (Rubatzky,1998).

Penggunaan pupuk organik sangat baik dalam rangka meningkatkan produksi pertania, karena pupuk organik selain meningkatkan kandungan unsur hara juga dapat memperbaiki sifat fisik dan 
biologi tanah (Soegiman, 1992). Salah satu alternatif untuk mempertahankan dan meningkatkan kesuburan tanah adalah dengan pemberian pupuk organik. Penggunaan pupuk organik mampu menjadi solusi dalam mengurangi aplikasi pupuk an organik karena mampu memperbaiki sifat fisik, kimia, dan biologi tanah, sehingga dapat meningkatkan kualitas dan kuantitas hasil panen tanaman. Salah satu pupuk organik yaitu air cucian beras (leri). Leri mudah diperoleh petani dan ramah lingkungan, memiliki hargamurah mudah terjangkau oleh petani. Selain leri, air sisa teh yang dibuang dapat menjadi limbah rumah tangga yang berguna untuktanaman.

Berdasarkan pengalaman di lapang air sisa teh dapat menyuburkan tanaman.Hal ini menunjukkan bahwa sebagai limbah rumah tangga, air teh dapatdimanfaatkan sebagai pupuk bagi tanaman .Menurut Pambudi (2002) kandungan hara atau mineral air teh cukup beragam, baik unsur mikro maupun makro, namun secara ilmiah perlu dibuktikan kebenarannya. Dengan pemupukan ini dapat mengurangi penggunaan pupuk buatan yang harganya relatif mahal dan terkadang sulit diperoleh di pasaran. Berdasarkan latar belakang masalah tersebut di atas, kiranya perlu dilakukan penelitian "Uji Macam Penyiraman terhadap Hasil Tanaman Uwi" (Dioscorea allata) TUJUAN PENELITIAN

Adapun tujuan penelitian ini adalah : untuk mengetahui pengaruh macam penyiraman terhadap hasil uwi.

\section{METODE PENELITIAN}

\section{Lokasi dan Waktu Penelitian}

Penelitian dilaksanakan pada bulan Maret 2019 sampai dengan bulan Nopember 2019 di Kebun Percobaan yang berlokasi di Sekip, Kalurahan Banjarsari, Kecamatan Banjarsari, Kotamadya Surakarta.

\section{Bahan dan Alat Penelitian}

Bahan yang digunakan dalam penelitian ini adalah bahan tanaman uwi berupa umbi dibawah tanah dan air cucian beras, serta air ekstrak teh.

\section{Metode Penelitian}

Penelitian ini menggunakan rancangan baku Rancangan Acak Lengkap ( RAL ) dengan faktor tunggal yang terdiri dari tujuh 
perlakuan macam penyiraman ( $\mathrm{P}$ ), Sebagai berikut :

1. $\mathrm{P} 0=$ Penyiraman dengan air ( kontrol)

2. $\mathrm{P} 1=$ Penyiraman dengan leri 1 gelas

3. $\mathrm{P} 2=$ Penyiraman dengan leri 2 gelas

4. $\mathrm{P} 3=$ Penyiraman dengan leri 3 gelas

5. $\mathrm{P} 4=$ Penyiraman dengan ekstrak teh 1 gelas

6. $\mathrm{P} 5=$ Penyiraman dengan ekstrak teh 2 gelas

7. $\mathrm{P} 6=$ Penyiraman dengan ekstrak teh 3 gelas
Masing - masing perlakuan

diulang 4 kali, sehingga keseluuhan ada 28 satuan perlakuan penelitian. Data hasil penelitian dianalisis dengan menggunakan analisis ragam

\section{HASIL DAN PEMBAHASAN}

\section{Jumlah Umbi per Tanaman}

Hasil analisis ragam, menunjukkan bahwa perlakuan macam bahan dan dosis penyiraman berpengaruh sangat nyata terhadap jumlah umbi per tanaman. Setelah diuji lebih lanjut menggunakan uji beda nyata jujur (BNJ) pada taraf $5 \%$, hasilnya disajikan dalam Tabel 1.

Tabel 1. Rata-rata jumlah umbi per tanaman akibat perlakuan macam penyiraman (buah)

\begin{tabular}{lcc}
\hline \multicolumn{1}{c}{ Macam Bahan dan Dosis Penyiraman } & $\begin{array}{c}\text { Rata-Rata Jumlah } \\
\text { Umbi Per Tanaman } \\
\text { (buah) }\end{array}$ & $\begin{array}{c}\text { Hasil Uji } \\
\text { BNJ 5\% }\end{array}$ \\
\hline $\mathrm{P}_{0}$ = Penyiraman dengan air ( kontrol) & 6,50 & $\mathrm{a}$ \\
$\mathrm{P}_{1}$ = Penyiraman dengan leri 1 gelas & 9,50 & $\mathrm{abc}$ \\
$\mathrm{P}_{2}$ = Penyiraman dengan leri 2 gelas & 9,75 & $\mathrm{abc}$ \\
$\mathrm{P}_{3}=$ Penyiraman dengan leri 3 gelas & 10,50 & $\mathrm{bc}$ \\
$\mathrm{P}_{4}=$ Penyiraman dengan ekstrak teh 1 gelas & 8,50 & $\mathrm{ab}$ \\
$\mathrm{P}_{5}=$ Penyiraman dengan ekstrak teh 2 gelas & 9,00 & $\mathrm{ab}$ \\
$\mathrm{P}_{6}=$ Penyiraman dengan ekstrak teh 3 gelas & 13,25 & $\mathrm{c}$ \\
\hline
\end{tabular}

\section{Keterangan :}

Rata-rata jumlah umbi per tanaman yang diikuti huruf sama berarti tidak nyata. Tabel 1 menunjukkan bahwa jumlah umbi per tanaman terbanyak diperoleh pada penyiraman dengan ekstrak teh 3 gelas $\left(\mathrm{P}_{6}\right)$ yaitu rata-rata 13,25 buah, tetapi tidak berbeda nyata jika dibandingkan dengan $\mathrm{P}_{1}$. 
$\mathrm{P}_{2}$, dan $\mathrm{P}_{3}$ yang menghasilkan

berturut-turut jumlah umbi per

tanaman rata-rata 9,5 buah, 9,75

buah, dan 10,50 buah.

\section{Berat Umbi per Tanaman (g)}

Hasil analisis ragam,menunjukkan dan dosis penyiraman berpengaruh sangat nyata terhadap berat umbi per tanaman. Setelah diuji lebih lanjut menggunakan uji beda nyata jujur (BNJ) pada taraf $5 \%$, hasilnya disajikan dalam Tabel 2.

bahwa perlakuan macam bahan

Tabel 2. Rata-rata berat umbi per tanaman akibat perlakuan macam penyiraman $(\mathrm{g})$

\begin{tabular}{lcc}
\multicolumn{1}{c}{ Macam Bahan dan Dosis Penyiraman } & $\begin{array}{c}\text { Rata-Rata Berat } \\
\text { Umbi Per Tanaman } \\
(\mathrm{g})\end{array}$ & $\begin{array}{c}\text { Hasil Uji } \\
\text { BNJ 5\% }\end{array}$ \\
\hline $\mathrm{P}_{0}$ = Penyiraman dengan air ( kontrol) & 737,50 & $\mathrm{a}$ \\
$\mathrm{P}_{1}$ = Penyiraman dengan leri 1 gelas & 975,00 & $\mathrm{ab}$ \\
$\mathrm{P}_{2}$ = Penyiraman dengan leri 2 gelas & 1000,00 & $\mathrm{ab}$ \\
$\mathrm{P}_{3}$ = Penyiraman dengan leri 3 gelas & 1175,00 & $\mathrm{ab}$ \\
$\mathrm{P}_{4}$ = Penyiraman dengan ekstrak teh 1 gelas & 787,50 & $\mathrm{a}$ \\
$\mathrm{P}_{5}$ = Penyiraman dengan ekstrak teh 2 gelas & 837,50 & $\mathrm{ab}$ \\
$\mathrm{P}_{6}$ = Penyiraman dengan ekstrak teh 3 gelas & 1242,50 & $\mathrm{~b}$ \\
\hline
\end{tabular}

\section{Keterangan :}

Rata-rata berat umbi per tanaman yang diikuti huruf sama berarti tidak nyata

Tabel 2 menunjukkan bahwa berat umbi per tanaman terberat diperoleh pada penyiraman dengan ekstrak teh 3 gelas $\left(\mathrm{P}_{6}\right)$ yaitu rata-rata 1242,50 $\mathrm{g}$, tetapi tidak berbeda nyata jika dibandingkan dengan $\mathrm{P}_{1} . \mathrm{P}_{2}, \mathrm{P}_{3}$, dan $\quad \mathrm{P}_{5} \quad$ yang berturut-turut menghasilkan berat umbi per tanaman rata-rata $975,00 \mathrm{~g}$, $1000,00 \mathrm{~g}, 1175,00 \mathrm{~g}$, dan 837,50 g.

\section{Volume Umbi (ml)}

Hasil analisis ragam, menunjukkan bahwa perlakuan macam bahan dan dosis penyiraman berpengaruh sangat nyata terhadap volume umbi. Setelah diuji lebih lanjut menggunakan uji beda nyata jujur (BNJ) pada taraf $5 \%$, hasilnya disajikan dalam Tabel 3. 
Tabel 3. Rata-rata volume umbi per tanaman akibat perlakuan macam penyiraman (ml)

\begin{tabular}{lcc} 
Macam Bahan dan Dosis Penyiraman & $\begin{array}{c}\text { Rata-Rata } \\
\text { VolumeUmbi Per } \\
\text { Tanaman }(\mathrm{ml})\end{array}$ & $\begin{array}{c}\text { Hasil Uji } \\
\text { BNJ 5\% }\end{array}$ \\
\hline $\mathrm{P}_{0}$ = Penyiraman dengan air ( kontrol) & 595,25 & $\mathrm{a}$ \\
$\mathrm{P}_{1}$ = Penyiraman dengan leri 1 gelas & 723,50 & $\mathrm{ab}$ \\
$\mathrm{P}_{2}$ = Penyiraman dengan leri 2 gelas & 789,00 & $\mathrm{ab}$ \\
$\mathrm{P}_{3}=$ Penyiraman dengan leri 3 gelas & 934,25 & $\mathrm{ab}$ \\
$\mathrm{P}_{4}=$ Penyiraman dengan ekstrak teh 1 gelas & 601,00 & $\mathrm{a}$ \\
$\mathrm{P}_{5}=$ Penyiraman dengan ekstrak teh 2 gelas & 717,75 & $\mathrm{ab}$ \\
$\mathrm{P}_{6}=$ Penyiraman dengan ekstrak teh 3 gelas & 994,25 & $\mathrm{~b}$ \\
\hline
\end{tabular}

Keterangan :

Rata-rata volume umbi per tanaman yang diikuti huruf sama berarti tidak nyata

Tabel 3 menunjukkan bahwa volume umbi terbesar diperoleh pada penyira-man dengan ekstrak teh 3 gelas $\left(\mathrm{P}_{6}\right)$ yaitu rata-rata 994,25 $\mathrm{ml}$, tetapi tidak berbeda nyata jika dibandingkan dengan $\mathrm{P}_{1} . \quad \mathrm{P}_{2}, \quad \mathrm{P}_{3}, \quad$ dan $\mathrm{P}_{5}$ yang menghasilkan volume umbi ratarata $723,50 \mathrm{ml}, 789,00 \mathrm{ml}, 934,25$ $\mathrm{ml}$, dan 717,75 ml.

\section{Berat Bulbil per Tanaman (g)}

Hasil analisis ragam menunjukkan bahwa perlakuan macam bahan dan dosis penyiraman berpengaruh sangat nyata terhadap berat bulbil per tanaman. Setelah diuji lebih lanjut menggunakan uji beda nyata jujur (BNJ) pada taraf $5 \%$, hasilnya disajikan dalam Tabel 4. yang menunjukkan bahwa berat bulbil per tanaman terberat diperoleh pada penyiraman dengan ekstrak teh 3 gelas $\left(\mathrm{P}_{6}\right)$ yaitu ratarata $4012 \mathrm{~g}$, tetapi tidak berbeda nyata jika dibandingkan dengan $\mathrm{P}_{3}$ yang menghasilkan berat bulbil per tanaman rata-rata 2927,75 g.

Tabel 4. Rata-rata berat bulbil per tanaman akibat perlakuan macam penyiraman $(\mathrm{g})$.

\begin{tabular}{lcc} 
Macam Bahan dan Dosis Penyiraman & $\begin{array}{c}\text { Rata-Rata Berat } \\
\text { Bulbil Per Tanaman } \\
(\mathrm{P})\end{array}$ & $\begin{array}{c}\text { Hasil Uji } \\
\text { BNJ 5\% }\end{array}$ \\
\hline $\mathrm{P}_{0}=$ Penyiraman dengan air ( kontrol) & 1099,50 & $\mathrm{a}$ \\
$\mathrm{P}_{1}=$ Penyiraman dengan leri 1 gelas & 1325,75 & $\mathrm{a}$ \\
$\mathrm{P}_{2}=$ Penyiraman dengan leri 2 gelas & 1607,75 & $\mathrm{a}$ \\
$\mathrm{P}_{3}=$ Penyiraman dengan leri 3 gelas & 2727,75 & $\mathrm{~b}$ \\
$\mathrm{P}_{4}=$ Penyiraman dengan ekstrak teh 1 gelas & 1345,50 & $\mathrm{a}$ \\
$\mathrm{P}_{5}=$ Penyiraman dengan ekstrak teh 2 gelas & 1774,00 & $\mathrm{a}$ \\
$\mathrm{P}_{6}=$ Penyiraman dengan ekstrak teh 3 gelas & 3922,00 & $\mathrm{c}$ \\
\hline
\end{tabular}




\section{Volume Bulbil (ml)}

$$
\begin{aligned}
& \text { Hasil analisis ragam, } \\
& \text { menunjukkan bahwa perlakuan } \\
& \text { macam bahan dan dosis } \\
& \text { penyiraman berpengaruh sangat }
\end{aligned}
$$

nyata terhadap volume bulbil.

Setelah diuji lebih lanjut menggunakan uji beda nyata jujur (BNJ) pada taraf $5 \%$, hasilnya disajikan dalam Tabel 5.

Tabel 5. Rata-rata volume bulbil per tanaman akibat perlakuan macam penyiraman $(\mathrm{ml})$

\begin{tabular}{lcc}
\hline \multicolumn{1}{c}{ Macam Bahan dan Dosis Penyiraman } & $\begin{array}{c}\text { Rata-Rata Volume } \\
\text { Bulbil }(\mathrm{ml})\end{array}$ & $\begin{array}{c}\text { Hasil Uji } \\
\text { BNJ 5\% }\end{array}$ \\
\hline $\mathrm{P}_{0}$ = Penyiraman dengan air ( kontrol) & 6,50 & $\mathrm{a}$ \\
$\mathrm{P}_{1}$ = Penyiraman dengan leri 1 gelas & 9,00 & $\mathrm{abc}$ \\
$\mathrm{P}_{2}$ = Penyiraman dengan leri 2 gelas & 10,50 & $\mathrm{bc}$ \\
$\mathrm{P}_{3}$ = Penyiraman dengan leri 3 gelas & 9,50 & $\mathrm{abc}$ \\
$\mathrm{P}_{4}$ = Penyiraman dengan ekstrak teh 1 gelas & 8,50 & $\mathrm{ab}$ \\
$\mathrm{P}_{5}$ = Penyiraman dengan ekstrak teh 2 gelas & 9,75 & $\mathrm{abc}$ \\
$\mathrm{P}_{6}$ = Penyiraman dengan ekstrak teh 3 gelas & 12,50 & $\mathrm{c}$ \\
\hline
\end{tabular}

Keterangan :

Rata-rata volume bulbil per tanaman yang diikuti huruf sama berarti tidak nyata

Tabel 5 menunjukkan bahwa volume bulbil terbesar diperoleh pada penyiraman dengan ekstrak teh 3 gelas $\left(\mathrm{P}_{6}\right)$ yaitu rata-rata $12,50 \mathrm{ml}$, tetapi tidak berbeda nyata jika dibandingkan dengan $\mathrm{P}_{1}, \mathrm{P}_{2}, \mathrm{P}_{3}, \mathrm{P}_{4}$ dan $\quad \mathrm{P}_{5}$ yang berturut-turut menghasilkan volume bulbil rata-rata 9,00 ml, 10,50 ml, 9,50 ml, 8,50 ml, dan $9,75 \mathrm{ml}$.

\section{B. Pembahasan}

Macam penyiraman berpengaruh terhadap peningkatan hasil uwi pada variabel jumlah umbi per tanaman, berat umbi, volume umbi, berat bulbil per tanaman, dan volume bulbil per tanaman;

Hasil penelitian jumlah umbi menunjukkan bahwa penyiraman menggunakan ekstrak teh 1 gelas (P4) dan ekstrak teh 2 gelas (P5) menghasilkan jumlah umbi sebanyak 9,00 buah dan 9,75 buah; hasil umbi ini tidak berbeda nyata jika dibandingkan dengan penyiraman menggunakan air (P0) yang menghasilkan 6,50 buah. Perbedaan jumlah umbi secara nyata baru terjadi setelah penyiraman menggunakan 
ekstrak teh dengan 3 gelas (P6) yang menghasilkan 13,25 buah dibanding P0, tetapi tidak berbeda nyata jika dibandingkan dengan penyiraman menggunakan leri 1 gelas (P1), menggunakan leri 2 gelas (P2), dan menggunakan leri 3 gelas (P3), yang berturut-turut menghasilkan 9,50 buah, 9,75 buah, 10,50 buah.

Terjadinya peningkatan jumlah umbi secara nyata tersebut di atas diduga karena pada penyiraman dengan ekstrak teh sebanyak 3 gelas dapat memenuhi kebutuhan tanaman akan berbagai unsur yang diperlukan dalam mendukung peningkatan jumlah umbi. Hal ini sesuai dengan pendapat Stephena (2004) yang menyatakan bahwa kandungan teh yang mengandung sejumlah mineral (Zn, Se, Mo, dan Mg) merupakan unsur-unsur yang dibutuhkan tanaman; apabila kekurangan salah satu dari unsur-unsur tersebut maka pertumbuhan dan hasil akan terganggu dan mengalami defisiensi.

Hasil penelitin berat umbi menunjukkan bahwa penyiraman menggunakan leri sebanyak 1 gelas $(\mathrm{P} 1), 2$ gelas $(\mathrm{P} 2)$, dan 3 gelas $(\mathrm{P} 3)$ akan meningkatkan berat umbi menjadi berturut-turut $975,00 \mathrm{~g}$, $1.000 \mathrm{~g}$, dan $1.175 \mathrm{~g}$, tetapi hasil ini tidak berbeda nyata jika dibandingkan dengan penyiraman menggunakan air (P0) yang menghasilkan berat umbi sebesar 737,50 g. Begitu pula dengan penyiraman menggunakan ekstrak teh sebanyak 1 gelas (P4) dan 2 gelas (P5) akan meningkatkan berat umbi menjadi $787,50 \mathrm{~g}$ dan $837,50 \mathrm{~g}$ tetapi juga tidak berbeda nyata jika dibandingkan dengan P0. Perbedaan berat umbi secara nyata baru terjadi setelah penyiraman menggunakan ekstrak teh sebanyak 3 gelas karena dapat meningkatkan berat umbi menjadi $1.242,50$ g per tanaman.

Hasil penelitian berat umbi per tanaman tersebut menunjukkan bahwa ada korelasi positif dengan jumlah umbi per tanaman, dimana meningkatnya jumlah umbi per tanaman akan meningkatkan berat umbi per tanaman.

Hasil penelitian volume umbi menunjukkan bahwa penyiraman menggunakan leri sebanyak 1 gelas (P1), 2 gelas (P2), dan 3 gelas (P3) akan meningkatkan volume umbi menjadi berturut-turut $723,50 \mathrm{ml}$, $789,00 \mathrm{ml}$, dan $934,25 \mathrm{ml}$, tetapi tidak 
berbeda nyata jika dibandingkan dengan penyiraman menggunakan air (P0) yang menghasilkan volume umbi sebesar 595,25 ml. Begitu pula dengan penyiraman menggunakan ekstrak teh sebanyak 1 gelas (P4) dan 2 gelas (P5) akan meningkatkan volume umbi menjadi berturut-turut $601,00 \mathrm{ml}$ dan 717,75 $\mathrm{ml}$, tetapi juga tidak berbeda nyata dengan $\mathrm{P} 0$. Perbedaan nyata baru terjadi setelah penyiraman menggunakan ekstrak teh sebanyak 3 galas (P6) karena dapat meningkatkan volume umbi menjadi 994,25 ml.

Hasil penelitian ini menunjukkan bahwa ada korelasi positip antara berat umbi dan volume umbi dimana meningkatnya umbi akibat penyiraman dengan macam bahan dan dosis penyiraman yang berbeda akan diikuti dengan peningkatan volume umbi.

Hasil penelitian berat bulbil menunjukkan bahwa penyiraman menggunakan leri sebanyak 1 gelas (P1) dan 2 gelas (P2) akan menghasilkan bulbil yang lebih berat yaitu rata-rata $1.325,75 \mathrm{~g}$ dan $1.607,75 \mathrm{~g}$, tetapi tidak berbeda nyata jika dibandingkan dengan penyiraman menggunakan air (P0) yang menghasilkan bulbil seberat rata-rata 1.099 .50 g. Peningkatan berat bulbil secara nyata baru terjadi setelah penyiraman menggunakan leri sebanyak 3 gelas karena dapat menghasilkan bulbil seberat rata-rata 2,727,75 g, Selanjutnya, penyiraman menggunakan ekstrak teh sebanyak 1 gelas (P4) dan 2 gelas (P5) juga akan meningkatkan berat bulbil menjadi rata-rata $1.345,50 \mathrm{~g}$ dan $1.774 .00 \mathrm{~g}$. tetapi tidak nyata jilka dibandingkan dengan P0. Peningkatan berat bulbil secara nyata baru terjadi setelah penyiraman menggunakan ekstrak teh sebanyak 3 gelas (P6) karena dapat menghasilkan bulbil seberat rata-rata $3.922,00 \mathrm{~g}$.

Meningkatnya berat bulbil akibat penyiraman menggunakan leri dengan dosis 3 gelas tersebut menunjukkan bahwa pada dosis ini kebutuhan tanaman akan nutrisi seperti vitamin B1, vitamin B3, vitamin B6, mangan, fosfor, dan zat besi (Hasanah, 2011, dalam bahar, 2018) telah tercukupi sehingga tanaman dapat memanfaatkannya untuk meningkatkan berat bulbil. Sedangkan meningkatnya berat bulbil 
akibat penyiraman menggunakan ekstrak teh dengan dosis 3 gelas menunjukkan bahwa pada dosis ini kebutuhan tanaman akan mineral seperti carbon organik, tembaga, magnesium, kalsium, serta serat kasar, selulosa, dan lignin (Ningrum, 2010) tercukupi sehingga tanaman dapat memanfaatkanya untuk meningkatkan berat bulbil.

Hasil penelitian volume bulbil terlihat bahwa penyiraman menggunakan leri sebanyak 3 gelas (P3) akan menghasilkan volume bulbil yang lebih besar yaitu rata-rata $10,50 \mathrm{ml}$ tetapi tidak nyata jika dibandingkan dengan penyiraman menggunakan air (P0) yang menghasilkan volume bulbil paling kecil yaitu rata-rata $6,50 \mathrm{ml}$; begitu pula jika dibandingkan dengan penyiraman menggunakan leri sebanyak 1 gelas (P1) dan 2 gelas (P2) yang menghasilkan volume bulbil berturut-turut $9,00 \mathrm{ml}$ dan $9,50 \mathrm{ml}$, ternyata juga tidak berbeda. Selanjutnya penyiraman menggunakan ekstrak teh sebanyak 1 gelas (P4) dan 2 gelas (P5) tidak berpengaruh nyata terhadap peningkatan volume bulbil dibanding
P0. Peningkatan volume bulbil secara nyata baru terjadi setelah penyiraman menggunakan ekstrak teh sebanyak 3 gelas karena dapat menghasilkan vulume bulbil terbesar yaitu rata-rata $12,50 \mathrm{ml}$, tetapi tidak berbeda nyata jika dibandingkan dengan P1, P2, P3, dan P5.

Meningkatnya volume bulbil secara nyata akibat penyiraman menggunakan leri dengan dosis 3 gelas tersebut menunjukkan bahwa pada dosis ini kebutuhan tanaman akan nutrisi seperti vitamin B1, vitamin B3, vitamin B6, mangan, fosfor, dan zat besi (Hasanah, 2011, dalam bahar, 2018) telah tercukupi sehingga tanaman dapat memanfaatkannya untuk meningkatkan volume bulbil. Sedangkan meningkatnya volume bulbil secara nyata akibat penyiraman menggunakan ekstrak teh dengan dosis 3 gelas menunjukkan bahwa pada dosis ini kebutuhan tanaman akan mineral seperti carbon organik, tembaga, magnesium, kalsium, serta serat kasar, selulosa, dan lignin (Ningrum, 2010) tercukupi sehingga tanaman dapat memanfaatkanya untuk meningkatkan volume bulbil. 


\section{KESIMPULAN}

Berdasarkan hasil penelitian dan pembahasan, dapat disusun kesimpulan sebagai berikut:

1. Penyiraman tanaman uwi menggunakan leri dengan dosis 3 gelas dapat meningkatkan secara nyata komponen hasil uwi yaitu jumlah umbi dan berat bulbil.

2. Penyiraman tanaman uwi menggunakan ekstrak teh dengan dosis 3 gelas dapat meningkatkan secara nyata komponen hasil uwi yaitu jumlah umbi, berat umbi, volume umbi, berat bulbil, dan volume bulbil.

3. Penyiraman tanaman uwi menggunakan ekstrak teh dengan dosis 3 gelas akan menghasilkan umbi terberat yaitu 1242,50 g/tanaman.

\section{DAFTAR PUSTAKA}

Anonim., 2015. UPGK Terus Lestarikan Uwi Tanaman Umbi Lokal Pengganti Pangan. www.news.com henk widi, Indobarat, M.E. Bidjodirajo Sumatra. Djakses pada : 9 Maret 2017.

Bahar, A.E., 2016. Pengaruh Pemberian Limbah Air Cucian Beras Terhadap Pertumbuhan Tanaman
Kangkung Darat. Riau : Fakultas Pertanian Universitas Pasip Pangaraian.

Ningrum., 2010. Pemanfaatan Ampas Tebu dan Ampas Teh Sebagai Media Tanam Terhadap Pertumbuhan Tanaman Cabe Ditinjau Dari Intennsitas Penyiraman Air Teh. Surakarta : UMS.

Pambudi, J., 2000. Potensi Teh Sebagai sumber Gizi dan Peranannya Dalam Kesehatan. Proseding Seminar Sehari Teh Untuk Kesehatan. Bandung : Pusat Penelitian Teh dan Kina Gambung.

Rubatzky dan Yanaguchi., 1998. Sayuran Duani 3 (tiga). Bandung : ITB.

Soegiman,1992.Ilmu Tanah. Terjemahan Bucman H.o and Brady. 1962. The Nature and Properties of Soil.Bratara Karya Aksara

Yuliana,2011. Potensi dan Prospek Pengembangan Uwi dalam Mendukung Ketahanan Pangan diNTT. Kupang : Fakultas PertanianNusa Cendana 